\title{
A Choice among Love, Money and Marriage: An Analysis on Values in Vanity Fair
}

\author{
Gaixia Wang ${ }^{1, \text { a }}$ \\ ${ }^{1}$ School of Foreign Languages, Neijiang Normal University, Neijiang 641199, China \\ a735669253@qq.com
}

Key words: Vanity Fair; values; love; money; marriage;

\begin{abstract}
Thackeray's novel Vanity Fair represents profoundly and vividly the society of London in the Victorian Age. The two girls in the novel, Amelia and Becky, make different value choices among love, money and marriage. This paper probes into the their difference in the value choice of love, money and marriage, reveals the underlying causes of Amelia's value choice, and further analyzes the author's implication, thus revealing the novel's deep social criticism.
\end{abstract}

\section{Introduction}

Vanity Fair is acknowledged as Thackeray's masterpiece. The title of the novel originates from John Bunyan's The Pilgrim's Progress while the subtitle “A Novel without A Hero” insinuates the author's intention to portray a notorious "vanity fair" on the whole. The novel narrates the lives of two contrasting girls in the context of the Napoleonic Wars. The protagonist Amelia Sedely is a gentle young lady coming from an affluent merchant family in London while Becky Sharp is an French orphan. The Amelia is characterized as the combination of tenderness, sentimentality and selfishness. Becky, a craftily unscrupulous and resourceful girl, stick to the way of wealth accumulation and position promotion. Be it lies or other despicable means, what she attempts is to actualize her vanity dream. The author's depiction of the two girls mirrors a vanity picture of capitalism.

\section{Value Differences in Vanity Fair: Love, Money and Marriage}

The novel reveals three types of value in Vanity Fair, that is, the values among love, money and marriage. "Character is at the center of our interest because in character we may see many facets of the people we meet in our daily life and even of ourselves." [1] The colorful picture of Vanity Fair consists of different characters and each of them shows different values.

Amelia's tender, kind-hearted and sentimental image is presented at the beginning. Her every manner shows us a so-called fair lady. As for the value of love, she is faithful, obstinate and selfish. Lu Wei and He Chengquan comment that Amelia is idealistic about love. Her value of marriage is a little different from that of love. She never uses marriage as a weapon to get wealth. Desiring Dobbin's help, she doesn't control him through marriage. Selfish as she is, she considers love and marriage sacred. Although Amelia never links money to marriage, money itself also plays an important role in her life, especially after the birth of her little George. When old Osborne wants to take his grandson away with money, Amelia simply says "Take money to part from my child! Who dares insult me by proposing such a thing?” [2] At this time, readers can see a woman with strong disdain for money. But later on, when faced with financial difficulty, she has to sell her shawl. He even give up young George because she has not enough money to bring him up, let alone give him a comfortable life. In the end the child, Amelia's treasure, leaves her and enters Mr. Osborne’s house. In fact, Amelia has to make a concession to money.

As far as Becky's three values are concerned, money plays an important role. In her time, every lady desires a decent marriage, and marries an aristocrat man. It can be even said that marriage is a woman's fate. And Becky's love is linked to four persons at least, though she marries once. When 
meeting Amelia's brother Joseph first, she thinks to herself "If Mr. Joseph is rich and unmarried, why should I not marry him?"[2] She put money at first, which has nothing to do whether she loves Joseph or not. After the failure of her pursuit of Joseph, she turns to Old Pitt. As soon as she goes to Hampshire, she casts Old Pitt's attention, pretending to be agreeable and useful in many different ways, such as playing cards with him in the evening, reading over with untiring patience all his law papers, so and so forth. To Old Pitt, Becky has become a companion. Chances are that she cannot wait for being the wife of Old Pitt, because she meets another richer person, Rawdon, the nephew of Miss Crawley and the inheritor of her property. It's a great pity that Miss Crawley never forgives or accepts their marriage. And Miss Crawley even makes a new will leaving everything to her elder nephew Pitt. It is really a bark to the moon for Becky. It is said love itself can present its most beautiful point in a lady, because she concentrates the love in her mental and real world. Only in love can she find the support of life. If she is unfortunate in love, then she will get lost as the wind blows out the fire. So it is with Becky's. As Guo Huixiang states, Rebecca utilize marriage as means of gaining wealth, power and social position. [2] Becky holds such an abnormal attitude toward love that she suffers a lot from it step by step.

If we say Becky's values of love and marriage are based on money, what kind of attitude toward money does she hold? When Miss Pinkerston asks Becky to instruct the children in music, Becky says "I am here to speak French with the children, not to teach them music, and save money for you. Give me money, and I will teach them." [4] Young as Becky is, she has already known the importance of money. To Becky, money means good reputation and wealth. But when she gets position she still desires to have much more money. "I have passed beyond it because I have brains," she said to herself. "I could not go back now and mix with the people I used to meet my father's...I wish I could exchange my position in society for a safe income.” [4] After reading Becky's thoughts, we can easily see that she never knows that enough is as good as feast.

In fact the two girls' different values of love, money and marriage represent an obvious phenomenon in the Victorian Age respectively. Being the representative of the lower middle class, Becky Sharp makes the best of her tricks and the people around her to get a higher social position and keep her legs still in the "vanity fair". However, with the development of economy which gives people opportunity to get hold of abundant wealth, it is hard for them to get the chances to touch the central power of the society. And Amelia, the mirror of Becky, represents the vitality and virtue of the middle class, the readers can see hope for the middle class to realize its wish through Amelia's good ends.

\section{The Underlying Causes of Amelia's Values}

Every effect has its causes and Amelia's values can be ascribed to social and personal reasons.

\subsection{Social Reasons}

In the Victorian Age, females are confined to the roles of home by males without political rights or property, so they could only rely on marriage and man. In a men-dominated society, women have two choices: one is to abide by the tradition of womenfolk tenderly and seriously, the other is to challenge this men-dominated society. Amelia chooses the former. She is a kind and tender girl that worships her husband blindly. After the death of her first idol George, she devotes all her energies to her little son George. Being proud of her son, Amelia often shows his drawing and composition to the relatives. To Amelia, her sons' works are all masterpieces. She is a typical good wife and loving mother, a doll that is controlled by the society at the same time. And the society needs such an obedient lady. And her personality has been formed by the western civilization in the Victorian Age. Amelia is nobody but the accessory of the society.

\subsection{Influence of Amelia's Social Circle}

It is said that the environment can shape a person. If we take Amelia's family as her inborn environment, then her social circle is acquired, which cannot be ignored, either. Amelia seldom goes 
to some balls, but the upper class never detaches from the ball. And her appearance at the ball in Brussela is a complete failure, as she does not know a single person there and no person cast a glance at her. Let's trace back to her school time, because the school is also a small society. "Why was it that Amelia, who had so many friends at school, should come out into the world to be disliked by other females? The answer is: there were no men at Miss Pinkerston's for the girls to quarrel about.” [2]The author has told us directly that Amelia is popular among girls in Miss Pinkerston's School, but not in the upper class's ball. In fact her social circle is connected with George closely. Although she is not accepted in such a social circle, Amelia is perfectly happy to go there. Like what Gao yuan and Song Laiquan (2006) state, to her, love is her religion, marriage is her only aim. [3] She cannot see anything except these aims and she likes to be possessed, or even controlled.

\subsection{Influence of Amelia's Family-A Mini-society}

As the family is a little society, it is need to analyze Amelia's family too. Amelia, a daughter of a rich merchant, represents the upper class. The author gives a direct and indirect depiction of her family. The indirect depiction begins at the first chapter. "A large family coach, with two fat horses, driven by a fat coachman." [2] This short depiction shifts the attention of the readers to the word "fat". The coachman is fat, and the horse is fat too. It's not hard to say that Amelia has a well-off family. The direct depiction always comes up with Becky's speaking and thinking. "She (Amelia) has ten thousand pounds, and her future comfortably settled." [2] "How lucky you are, who have only to drive to the shops with your mother, who will give you anything you ask!" [2]It is the rich family that determines Amelia's values of love, money and marriage. In her early years, she needs not to think about money. So her value of love is love itself. Her falling in love with George has nothing to do with money.

But later on after her family's decline, money is also a problem for Amelia. It is Dobbin who always helps her, giving her money and buying presents for young George. From her family's prosperity and decline, we can also see how the temptation of money really affects people's values.

\subsection{The Author's Attitude toward the Three Values}

If we agree that the world of literature is a reflection of the world of reality, we can come to a conclusion that the values in Vanity Fair are a reflection of those in Thackeray's time. As far as many common people are concerned love and marriage are based on money. As it often happens in the society, Amelia and her husband George Osborne's marriage is based on the two families' arrangement. However, when Amelia's father lost his fortune the old Osborne even urges his son to marry another wealthy woman. From this example, we may get to know that in some people's eyes, love and marriage are equal to money. And as money itself is concerned, most conflicts in the novel are connected with it. In the novel Mrs. Bute Crawley wants to gain Miss Crawley's money, so she urges Rawdon, the inheritor of Miss Crawley, to marry Becky. In this way, Radown loses his aunt, Miss Crawley's favor, so Mrs. Bute would have the chance of having the money. In one word, to a majority of people values money most.

However, the author's attitude toward the three values is quite different from that of common people. At the end of the novel, the author said "Ah! Vanitas Vanitatum! Which of us is happy in this world? Which of us has desire? Or, having it, is satisfied?” [2] In this vanity world, most people try eagerly to gain name, money and position, only Thakeray himself takes these with a tongue of half irony and half humor. The reason why he does so can be traced back to his life.

To Thackeray, the society was diseased as it was morally corrupted, because most people were money-oriented. It seemed that he was indifferent to the three values, for he himself suffered from this society in his early years. Thackeray, the son of an East India Company official, was born at Calcutta in 1811. Young Thackeray grew up in the same fashion as other upper middle class Englishmen of the time. After returning to England, Thackeray lived the life of a propertied young gentleman. But later at the age of 22, he lost the fortune he inherited from his father due to the failure of the Indian bank where he had deposited his money. In order to earn his living, he first worked as an artist and illustrator, and then wrote for various magazines. It was the publication of Vanity Fair in 
1848 that settled his position as a great novelist of the day. In his childhood he felt the coldness of the society, for his family was Anglo-Indian to whom the English society was hostile. Living in the upper middle class, he was familiar with the life of upper society, which in turn offered him enough materials to reflect the ugly phenomenon in Victorian Age.

We can come to know such a fact from the novel that no matter it is Becky who racks her brains in scheming to change the life or Amelia who resigns herself to adversity, but neither of them can be freed from the society's fetters. Their misfortune is a suffering of all females in the capitalism. The author even does not blame Becky but depicts her like this. "If Miss Rebecca Sharp had determined in her heart upon making the conquest of this big geau, I don't think, ladies, we have any right to blame her, for though the task of husband-hunting is generally, and with becoming modesty, entrusted by young people to their mammas, recollect that if she did not get a husband of herself, there was no one else in the wide world who would take the trouble of her hands.”[2] We will get the author's implied meaning, which is the corruption of the society that models such kind of person. It seems that everybody is right, and the world is a rogue. The author expresses that the corruption of the society is nobody's fault. "He took it as his duty to expose the vices of his age, especially those popular in the upper-middle class. And he regarded snobbery and money-grabbing with all possible means as the chief vice in his society."[2] Reading over this depiction, we must feel the author's half sympathy and half irony. It is the corruption of the society that makes the appearance of these two kinds of people.

\section{Conclusion}

Thackeray examines the females in the Victorian Age through his calm eyes and analyzes their living environments through a realist technique, especially their different values of love, money and marriage.Although Amelia and Becky show different values of love, money and marriage, they represent a whole society, no matter they challenge or submit to it. Both of them are accessories and victims of the society, only in different ways. In author's words, "which of us is happy in this world? Which of us has his desire? Or, having it, is satisfied?" [4]It is no other than society that should be blamed, just like there is no winner in the choice among love, money and marriage.

\section{References}

[1] Yuan Xianjun, Qian Quanqiang. Approaching Fiction [M]. Beijing: Peking University Press. 2004:68.

[2] Guo Huixiang. Victim or Victimizer: Analysis of Becky Sharp in Vanity Fair [J]. Journal Xinxiang Teachers College, 2005(4): 88-89.

[3] Gao Yuan, Song Laiquan. Understanding the Reality of Society from Rebellion: The Life of Becky's Revolt in Vanity Fair [J] Journal of Xinxiang Institute of Education, 2006 (1): 26-28.

[4] Thackeray, W.M. Vanity Fair [M]. Shanghai: Shanghai Foreign Language Education Press, 2001. 